\title{
CONSCIOUS CONTROL IN SPEECH PATHOLOGY AND SPEECH REHABILITATION FOLLOWING STROKE
}

\author{
Tetyana Pastryk \\ tanyushagp@gmail.com \\ Lutsk Medical College, Ukraine \\ Olena Kotys \\ olena.khad@gmail.com \\ Lesya Ukrainka Eastern European National University, Ukraine \\ Nataliia Dyachuk \\ natadiachuk@gmail.com \\ Ivan Franko Zhytomyr State University, Ukraine \\ Volodymyr Milinchuk \\ milincuk85@gmail.com \\ Lutsk Medical College, Ukraine
}

Received September 9, 2019; Revised November 22, 2019; Accepted December 3, 2019

\begin{abstract}
The article presents results of the research conducted in speech rehabilitation period of patients after stroke. The study aims to identify conscious control in speech rehabilitation period of the patients who were diagnosed to have Broca's aphasia. A sample of 22 patients with Broca's aphasia, or efferent motor aphasia (Luria, 2004) in the left hemisphere, who stayed at the Volyn Regional Clinical Hospital (Lutsk, Ukraine) during rehabilitation period, was approached through purposeful sampling method for this research. The non-laboratory measure of speech assessment was administered along with demographic data. Results showed that conscious control that usually remains in this group of people plays a crucial role in psychological intervention. The article also discusses the main neuropsycholinguistic principles that help to utilize the potential of conscious control in the process of speech rehabilitation of the patients after stroke.
\end{abstract}

Keywords: stroke, Broca's aphasia, conscious control, speech pathology, speech rehabilitation, neuropsycholinguistic principles.

Пастрик Тетяна, Котис Олена, Дячук Наталія, Мілінчук Володимир. Свідомий контроль у мовленнсвій патології та мовленнсвій реабілітації після інсульту.

Анотація. Статтю присвячено результатам мовленнєвої реабілітації пацієнтів після інсульту. Дослідження мало за мету встановити аспекти свідомого контролю під час мовленнєвої реабілітації осіб із афазією Брока, або моторної еферентної афазії (Лурія, 2004), лівої півкулі. Вибірку склали 22 пацієнти Волинської обласної клінічної лікарні в Луцьку (Україна) упродовж реабілітаційного періоду. Дослідження здійснено на основі методів цільового формування вибірки, а також застосування неапаратурного методу оцінки мовлення разом із демографічними даними. Результати засвідчили, що свідомий контроль у цієї групи осіб відіграє ключову роль під час психологічної інтервенції. Крім того, автори обговорюють головні нейропсихолінгвістичні принципи, що сприяють вико-

(C) Pastryk, Tetyana; Kotys, Olena; Dyachuk, Nataliia; Milinchuk, Volodymyr, 2019. This is an Open Access article distributed under the terms and conditions of the Creative Commons Attribution 4.0 International Licence (http://creativecommons.org/ licenses/by/4.0).

East European Journal of Psycholinguistics, 6(2), 89-97. https://doi.org/10.5281/zenodo.3637746 
ристанню потенціалу свідомого контролю в процесі мовленнєвої реабілітації пацієнтів після інсульту.

Ключові слова: інсульт, афазія Брока, свідомий контроль, мовленнєва патологія, мовленнєва реабілітація, нейропсихолінгвістичні принципи.

\section{Introduction}

In modern anthropogenic society with its rapid pace and stressful as well as ecologically harmful factors we can observe increase of cardiovascular diseases, stroke being the most widely spread. This medical condition is characterized by accidental disruption of blood supply to the brain with possibility of movement disorders, coordination and speech, causes communication disorders, social role change, resulting in a psychological trauma for an individual and their social context as well. When dealing with a stroke, its sudden nature and damage area (the brain) should be considered. Since the brain is the most complex body organ, damage of its parts causes various functional disorders.

Analysis of recent research on speech aphasia of patients after stroke (Hauk, Johnsrude, \& Pulvermüller, 2004; Brown \& Hagoort, 2003; Fawcus, 2000; Marshall, 2000a, 2000b; Northoff, 2003; Хомская, 2005; Шохор-Троцкая, 2001) shows that most part of research in the field is being conducted in laboratories and aims to investigate clear correspondence between speech features and localization of injury. However, laboratory testing methods are inferior to empirical ones when it comes to deep observation and examination of participants' behavior, holding conversations with them; it is the time when psycho-corrective work usually takes place. It involves activities for speech therapy and it considers psychological states and health condition of a patient.

The topic of this research is of great current interest, because one of the most serious stroke consequences is speech disorder or its total loss, and that is why stroke patients who get into this psycholinguistic "trap", face the situation when they are desperately trying to express themselves and say how they feel or what they need; this causes aggressive behavior, irritation and anxiety.

\section{Methods}

Speech impairment of patients after stroke is becoming common not just among the elderly patients, but also among middle-aged people as well as young ones. Notwithstanding the fact that the research on nature of speech disorders caused by a stroke and investigation of speech correction methods is being done, Ukrainian scholars haven't studied these phenomena to the full yet. It can partly be explained by the difficulties that researchers face when they start speech diagnostics of stroke patients. Also, the patients' behavior may challenge researchers and cause obstacles. At the same time, as experience shows, there is a need in applied research on speech peculiarities of stroke patients to help them restore their speech function during the rehabilitation period. This idea brings us to the main goal of this research 
which is to determine the role of conscious control in speech function restoration of stroke patients with efferent motor aphasia.

A sample of 22 patients with Broca's aphasia, or efferent motor aphasia (Luria, 2004) in the left hemisphere, who stayed at the Volyn Regional Clinical Hospital in Lutsk, Ukraine during rehabilitation period, was approached through purposeful sampling method for this research. The non-laboratory measure of speech assessment was administered along with demographic data.

Efferent motor aphasia is considered to be one of the most severe speech pathologies resulting from lesions in the lower part of the left premotor area of the brain. The participants of our experiment (the subjects) are stroke patients who had stroke not later than one year ago. Such time criterion was chosen due to the common idea that spontaneous (without a psychologist being involved) speech recovery usually takes place during the time period of 12 months after the stroke had been diagnosed (Pulvermüller, 2002). All the remaining disorders can be considered as chronic, because they are very difficult to deal with during psychocorrective activities.

The empirical research was based on the experiment where the participants were asked to tell a story based on a thematic picture On Holiday using the nonlaboratory measure of speech method, introduced by Luria (2004). Each criterion was estimated using scale grading from 1 to 3 in which 1 is the lowest (basic) level of speech comprehensiveness and 3 is the highest (advanced) level. To identify the abovementioned levels we involved three experts, doctors of Neurology Department working at the Volyn Regional Clinical Hospital and a speech therapist.

\section{Results and Discussion}

The peculiarities of manifestation of various speech criteria in correlation with the level of speech comprehensiveness, that were identified by the expert group, are presented in Table1 below.

Table 1

Expert estimation of stroke patients' speech $(n=22)$

\begin{tabular}{lcl}
\hline \multicolumn{1}{c}{$\begin{array}{c}\text { Speech } \\
\text { criteria }\end{array}$} & $\begin{array}{c}\text { Speech comprehensiveness } \\
\text { degree of stroke patients } \\
\text { (1 to } 3 \text { points), } \\
\text { Mean (SD) }\end{array}$ & \multicolumn{1}{c}{$\begin{array}{c}\text { Content criteria of expert } \\
\text { estimation }\end{array}$} \\
\hline $\begin{array}{l}\text { Spontaneous } \\
\text { speech }\end{array}$ & 1.50 & $\begin{array}{l}\text { Basic level (1 point): from 1 to } \\
\text { (expressive }\end{array}$ \\
speech) & $(.41)$ & $\begin{array}{l}\text { level: } 6-10 \text { sentences (2 } \\
\text { points); advanced level: } 10\end{array}$ \\
sentences and more (3 points). \\
Automatic & 1.78 & $\begin{array}{l}\text { Basic level: automatic } \\
\text { repetition of one of three } \\
\text { tasks: numbers, days of the }\end{array}$ \\
\hline
\end{tabular}


Non-
automatic
speech

Repetition

Object

1.05

naming

Speech

comprehensio

$\mathrm{n}$ and

understanding

(impressive

speech) week (1 point); intermediate level: automatic repetition of two of three tasks (2 points); advanced level: automatic repetition of three tasks (3 points).

Basic level: non-automatic repetition of one of three tasks: numbers, days of the week (1 point); intermediate level: non-automatic repetition of two of three tasks (2 points); advanced level: non-automatic repetition of three tasks (3 points).

Basic level: repetition of one out of five series of language units: sounds, combinations of sounds, series of words, phrases ( 1 point); intermediate level: repetition of two out of five series of language units (2 points); advanced level: repetition of three or more out of five series of language units (3 points).

Basic level: fulfilling one of three tasks: naming objects using pictures, using instructions, naming series of objects (1 point); intermediate level: fulfilling two of three tasks (2 points); advanced level: fulfilling three tasks (3 points).

Basic level: fulfilling one of four tasks: understanding words using pictures, understanding meaning of words (body parts, without using visual aids), understanding low-frequency words, understanding simple instructions (1 point); 


\begin{tabular}{ll}
\hline & intermediate level: fulfilling \\
& two of the abovementioned \\
& tasks (2 points); advanced \\
& level: fulfilling three tasks \\
& from the list (3 points). \\
& Basic level: speech is not \\
& always grammatically correct, \\
Spontaneous & telegraph style of speech, \\
enlarged & weak correlation between \\
speech & expressions (in text fragments \\
(expressive & of less than 5 sentences); \\
speech) & intermediate level: \\
& grammatically correct \\
& structures and adequate use of \\
& language in a text fragment of \\
& up to 10 sentences (2 points); \\
& advanced level: grammatically \\
& correct structures and \\
& adequate use of language in \\
& text fragment of 10 and more \\
& simple and complex sentences \\
& (3 points)
\end{tabular}

As Table1 shows, patients face most difficulties during speech generation process (i.e., naming objects) and also spontaneous speech without any visual aids or pictures. Furthermore, the basic difficulties can be traced during active interview conducted by a psychologist when they asked the subjects about disease etiology and passage. We can observe much better speech performance when patients were asked about neutral or positive topics as, for instance, holiday and rest, especially when there were visual aids on the topic available. The experiment has shown domination of non-automatic speech characteristics over the ones of automatic speech. Non-automatic speech is characterized by high level of conscious control. This result correlates with our hypothesis that conscious control plays crucial role in positive speech rehabilitation of stroke patients.

Our original complex speech recovery program of stroke patients is based on non-literal principle as a way to rebuild functional systems; this corresponds to the dominant role of conscious control in positive speech dynamics. The program that we created correlates with methodology of neuropsycholinguistic research that combines empiric, epistemic and ontological approaches (see Table2). 
Table2

Content characteristics of psycho-corrective program according to the methodology of neuropsycholinguistic research

\begin{tabular}{ll}
\hline General scientific approaches & Content characteristics of the program \\
\hline Empirical approach & $\begin{array}{l}\text { Introduction of game activities in } \\
\text { cooperation of a psychologist and a } \\
\text { subject, fixation of features of speech } \\
\text { activity on the stages of thought } \\
\text { formation and speech performance } \\
\text { Reflection of subjects on their own } \\
\text { speech, feedback on their own } \\
\text { emotional and mental states } \\
\text { Considering compensatory } \\
\text { mechanisms of human brain and } \\
\text { Ontological approach } \\
\text { abilies of speech development as a } \\
\text { mental process }\end{array}$ \\
\hline
\end{tabular}

All the above mentioned shows that the results of a complex neuropsycholinguistic experiment with all the methodological requirements considered, enable researchers to not just create and introduce the clinical picture of efferent motor aphasia, but also to utilize a comprehensive psycho-corrective speech recovery program that combines the idea of unity of brain and mind of an individual.

Data received using computer-aided methods of research, that were collected during the period of hospital treatment, helped to compare and map activization of certain brain areas and specificity of a certain mental operation: its modality, duration and function. An important issue to consider is avoidance of direct neurophysiological parallelism that is used to match certain brain area with a certain cognitive operation; this does not correlate with A. Luria's fundamental principle of systemic localization of higher mental functions (Luria, 2004).

Using some of already existing research on the topic (Pulvermüller, 2002; Pulvermüller \& Berthier, 2008) we singled out the main directions of psychocorrective work: psycholinguistic correction using music, transcranial magnetic stimulation and pharmaceutical treatment.

Analysis of impressive speech retention degree has shown that aphasiacs tend to remember lexical units better if they have some visual aids at their disposal. We shall consider this fact when planning psycholinguistic correction work with these patients.

In order to effectively introduce psycho-corrective program and ensure positive dynamics of speech performance of the stroke patients we addressed the preserved functions of conscious behavior (i.e., conscious control function) when speaking. The importance and need to address this function are caused by the following: firstly, the results of our research involving people with efferent motor aphasia have 
shown better comprehensiveness of non-automatic speech as compared to automatic. In the process of automatic speech generation, when naming numbers, weekdays and months, the subjects made a few mistakes. Secondly, occurrence of mistakes in automatic speech can be explained by it being rather fast and in this case speech reactions can be rather impulsive. However, the results of the experiment prove that in the process of fulfilling tasks to check automatic speech performance, stroke patients are fast enough to find solutions to problems under consideration using wrong speech acts when identifying and choosing concrete language units. If production of language units is executed in the opposite order, non-automatic speech being involved, the participants fulfill the tasks and make decisions more slowly thus making fewer mistakes when identifying language units.

Conscious control function that should be addressed when working with speech performance of efferent motor aphasia patients can be utilized in the process of doing various speech exercises and thus improving how they are done. For instance, in the process of intensive speech correction activities the subjects were encouraged to think about the task thoroughly, to examine the suggested picture very carefully in order to avoid impulsive speech reactions and find the correct answer.

When asking participants to speak on the given picture, they were encouraged to take time and examine all the picture details thoroughly as well as to be reflexive when delivering their ideas.

Conscious control function is built upon close interrelation of various cognitive processes. That is why if to speak about this function and its retention in the context of efferent motor aphasia, we cannot but mention sufficient memory capacity, maturity of thinking ability and intelligence as a whole. The subjects were noticed to have the functions of voluntary and involuntary attention, because they were able to concentrate on a difficult and laborious task. Functions of the stroke patients' memory were also well-preserved: during the experiment the subjects asked to repeat series of sounds or words very rarely, trying to reproduce them on the first try. Space and time orientation, structuring narratives and comprehension of narrations in pictures show that intellectual processes of stroke patients are preserved.

Results of empirical and experimental research of speech of stroke patients diagnosed with efferent motor aphasia in rehabilitation period show the crucial role that is played by the functions of their consciousness, i.e., adequate mental reflection, construction of individual picture of the world and activity production on this basis (Luria, 2004). It is worth mentioning that notwithstanding the fact that negative emotional states of patients existed, accompanied with negative emotional cycles (protection, avoidance and activity limitation), in general the individual consciousness could be defined as clear and active. Negative feelings usually caused refusal to cooperate with a psychologist and also had negative impact on individual speech performance.

In the process of diagnostic and psycho-corrective work with stroke patients who were diagnosed with Broca's aphasia, it is important to consider retention of 
speech conscious control function that helps to develop and reinforce speech performance. In our opinion, the basic points to remember when working with patients after stroke should be the following:

- control and repression of impulsive and development of reflexive speech performance using various tasks of psycho-corrective work, since 'faster does not mean better';

- emphasis on retention of the mental processes that include memory, attention and thinking;

- stimulation of conscious control of speech performance as well as emotional states, preserving mental activity and dealing with protective and eluding behavior;

- concentration on non-automatic speech with slow transformation into automatic speech preserving reflexive speech performance, notwithstanding the fact that this task is easy.

It is reasonable to think that retention of conscious control of stroke patients with Broca's aphasia is a potential resource in positive speech performance dynamics during rehabilitation period.

\section{Conclusions}

Investigating speech of stroke patients who were diagnosed with efferent motor aphasia is one of few cases the results of which may profoundly influence the already existing inventory of neuropsychology and psycholinguistics. It is reasonable to talk about close connection between language and all the cognitive processes. However, speech, if compared to other mental processes, is the most exteriorized and it also bears intellectual abilities of a person as well as emotional states and motivation. Cohesiveness of language and thought in cognitive activity leads to the rise of term 'speech-and-thought activity'. Categorization of extralinguistic world is based on notions, ideas, conclusions that are somehow 'shaped' using natural language. On the other hand, efferent motor aphasia enables us to artificially separate speech from higher cognitive processes like thinking, memory, attention and to use the latter in order to help recover speech performance.

Following this, it is worth to consider not only compensatory abilities of human brain, but also compensatory abilities of the mind itself. Intellectual processes being retained, conscious control is used to generate speech.

Thus, the results of our research enable us to conclude that the principle of functional non-literality is not only of emotional, but also of cognitive nature. Its emotional nature helps to stimulate positive mental activity of a subject on the preparatory stage of intensive speech correction process. However, it is its cognitive nature that enables us to utilize conscious control and the retained cognitive processes to develop effective speech dynamics.

\section{References}

Лурия А.Р. Лекции по общей психологии. СПб.: Питер, 2004. 
Мілінчук В. І., Засєкіна Л. В. Нейропсихолінгвістичний підхід до дослідження мовлення пацієнтів після інсульту // Актуальні проблеми практичної психології. Ч. І. 2010. C. 143-146.

Мілінчук В. І. Вплив емоційних станів на мовленнєву діяльність пацієнтів після інсульту // Психологічні перспективи. Вип. 15. 2010. С. 207-218.

Хомская Е. Д. Нейропсихология. СПб.: Питер, 2005.

Шохор-Троцкая М. К. Речь и афазия. М.: Изд-во ЭКСМО-Пресс, 2001.

Brown C., Hagoort P. (2003). The Neurocognition of Language. Oxford: Oxford University Press.

Hauk, O, Johnsrude, I., \& Pulvermüller, F. (2004). Somatotopic representation of action words in motor and premotor cortex. Neuron, 41, 301-307.

Kohno, M. (2007). Two neural clocks: humans' innate temporal systems for spoken language processing. In J. Arabski, Ed. Challenging Tasks for Psycholinguistics in the New Century. (pp. 283-292). Katowice: University of Silesia.

Marshall, J. (2000a). Speech and language problems following stroke In R. Fawcus, Ed. Stroke Rehabilitation. (pp. 113-129). Oxford: Blackwell.

Marshall J. (2000b). The treatment of speech and language disorders following stroke. In R. Fawcus, Ed. Stroke Rehabilitation. (pp. 130-146). Oxford: Blackwell.

Northoff, G. (2003). Philosophy of the Brain. Boston: Harvard University.

Pulvermüller, F. (2002). The Neuroscience of Language. On Brain Circuits of Words and Serial Order. Cambridge: Cambridge University Press.

Pulvermüller, F., Berthier, M. L. (2008). Aphasia therapy on a neuroscience basis. Aphasiology, 22(6), 563-599.

\section{References (translated and transliterated)}

Luria, R. (2004). Lektsii po Obschey Psikhologii [Lectures on General Psychology]. S.-Petersburg: Piter.

Milinchuk, V., Zasiekina, L. (2010). Neuropsycholinhvistycgbyi pidhid do doslidzhennia movlennia patsientiv pislia insultu [Neuropsycholinguistic approach to the study of patients after stroke]. Aktualni Problemy Praktychnoi Psykholohii, 1, 143-146.

Milinchuk, V. (2010). Vplyv emotsiinykh staniv na movlennevu diyalnist patsientiv pislia insultu. Psyholohichni Perspectyvy - Psychologucal Prospects, 15, 207-218.

Khomskaya, Y. (2005). Neuropsihologiia [Neuropsychology]. S.-Petersburg: Piter.

Shohor-Trotskaya, M. (2001). Rech i Afaziya [Speech and Aphasia]. Moscow: Eksmo-Press.

Brown C., Hagoort P. (2003). The Neurocognition of Language. Oxford: Oxford University Press.

Hauk, O, Johnsrude, I., \& Pulvermüller, F. (2004). Somatotopic representation of action words in motor and premotor cortex. Neuron, 41, 301-307.

Kohno, M. (2007). Two neural clocks: humans' innate temporal systems for spoken language processing. In J. Arabski, Ed. Challenging Tasks for Psycholinguistics in the New Century. (pp. 283-292). Katowice: University of Silesia.

Marshall, J. (2000a). Speech and language problems following stroke In R. Fawcus, Ed. Stroke Rehabilitation. (pp. 113-129). Oxford: Blackwell.

Marshall J. (2000b). The treatment of speech and language disorders following stroke. In R. Fawcus, Ed. Stroke Rehabilitation. (pp. 130-146). Oxford: Blackwell.

Northoff, G. (2003). Philosophy of the Brain. Boston: Harvard University.

Pulvermüller, F. (2002). The Neuroscience of Language. On Brain Circuits of Words and Serial Order. Cambridge: Cambridge University Press.

Pulvermüller, F., Berthier, M. L. (2008). Aphasia therapy on a neuroscience basis. Aphasiology, 22(6), 563-599. 